\title{
Effectiveness of Cherry Leaf Extract (Muntingia Calabura) with Different Levels as Treatment of Seeds of Sangkuriang Catfish (Clarias Gariepinus) Infected by Trichodina SP
}

\author{
Mohammad Nurhuda ${ }^{1}$, Marry Ann Kholista ${ }^{1}$, Yuliani Ismi ${ }^{1}$, Nurfitri Maulidiya ${ }^{1}$, Hariyadi ${ }^{1}$, Riza \\ Rahman Hakim ${ }^{1}$
}

Fisheries Department, Faculty of Agriculture and Animal Science, University of Muhammadiyah Malang, Indonesia.

*harry.umm@gmail.com

\section{https://doi.org/10.22219/ijota.v1i1.5980}

\begin{abstract}
The aimed of this study is to evaluate of cherry leaf extract (Muntingia calabura) on hematocrit, leukocrit and anti-parasitic on sangkuriang catfish (Clarias gariepinus) post-infected by Trichodina sp. Cultivators experience constraints on seeding and enlargement of ectoparasites Trichodina sp. This parasite infected on the surface body with appear spots on the body. Prevention and treatment using many chemicals generated adverse effect such as residue, and environmental hazard. In other hand, Cherry Leaf contains Flavonoid, Tannin, Triterpenoid, Saponin and Polifenol compounds as antioxidants and antibacterial. This research used experimental method and Completely Randomized Design (RAL). Concentrations of cherry leaf extract (Muntingia calabura) were devided in $1 \%, 2 \%, 3 \%, 4 \%$ and $5 \%$ applied on 5 treatments and 4 replications. The data were analyzed using ANOVA method (variance analysis). The results revealed cherry leaf extract (Muntingia calabura) very good against Trichodina sp parasite. The best value of the leukocrit percentage showed by $2 \%$ concentration that decreased leukocrit percentage to $2.68 \%$ and increased percentage of hematocrit was increased $11.83 \%$ post-infected. The clinical study, funded white spots come out in all body, pale color appearance, decreased appetite and rubbing the body to the wall. Water quality measurement showed temperature: $24-27,2^{\circ} \mathrm{C}, \mathrm{DO} 4,1-6,9$ and $\mathrm{pH}: 6-8$.
\end{abstract}

Keywords: cherry leaf, Hematocrit, Leukocrit, Sangkuriang Catfish, Trichodina

\section{Introduction.}

Sangkuriang Catfish (C. gariepinus) become the leading commodity of Indonesian freshwater fishery. It is one source of animal proteins contributed for the nutritional needs of Indonesian society. In the present, the farmers still have a problem in the hatchery and enlargement phase of Sangkuriang catfish ( $C$. gariepinus). The hatchery phase have been known a vulnerable phase on disease invasion. The Trichodiniasis caused by Trichodina sp, one of the diseases, is often infected of freshwater fish included C. gariepinus seeds.

Trichodina sp, an ectoparasite and ciliate parasite, infect on the surface of the skin, fins and gill that is caused decreasing of immune system and generates secondary infection (Zheila, 2013). It infects by sticking to the epithelial layer of the fish with the hook. The hook destroys epithelial 
cells by twisting, then damaged epithelial cells (Yuasa, 2003). According to Gusrina (2008), Trichodina $\mathrm{sp}$ is characterized by the presence of white spots to gray and remove mucus. Characteristics of Clarias sp infected by Trichodina sp were looked dull color, visible limp and often rub their body against the wall or bottom of the pool.

Chemicals and antibiotics such as CuSO4 and Formalin have been used to prevent and treat of Trichodina sp infection (Mahasri, 2009). The use of chemicals such as formalin cause cancer for consumers, eye and skin irritation and respiratory disorders (Chanif, 2012). Based on SNI 01-67292002, natural ingredients could be an alternative to prevent of infection. The use of natural ingredients can reduce the residue and does not affect the environment and host. One of the materials that can be used is Leaf of Cherry (M. calabura).

Priharyanti, (2007) and Zakaria, (2007), Cherry Leaf contains Flavonoid, Tannin, Triterpene, Saponin and Polifenol as antioxidants. Cherry Leaf is also useful as an anti-bacterial (Sulistyaningrum, 2014). Polar compounds in Saponin, Flavonoid, and Tanin are active as antimicrobials by destroying cytoplasmic membranes and killing epidermal cells (Rahayu, 2008). This study was conducted to examine the effect of $M$. Calabura extract as anti-parasitic agent against Trichodina sp on Sangkuriang catfish (C. gariepinus).

\section{Materials and Methods}

The study was conducted in May - June 2017 at Fisheries Laboratory, Faculty of Animal Husbandry and Chemistry Laboratory of University of Muhammadiyah Malang. The research material was Sangkuriang catfish, cherry leaf, ethanol 96\%, FeCL3 1\%, HCL 2 N, concentrated H2SO4, concentrated H2SO4, Bouchartdat, and Dragendof, concentrated $\mathrm{HCl}, \mathrm{Mg}$ powder, Amyl alcohol, Filter paper, Catfish feed, NaCl Physiological, EDTA, Plastic Candle, Universal Indicator. The research tool was Aquarium, blower, scales, filter, microscope, glass concave object, DO meter, Eppendorf tube, hematocrit tube, syringe, rotatory evaporator, oven, Erlenmeyer, beaker glass, pumpkin, spatula, measuring pipette, blander, , water stone, aeration hose, aeration faucet, paralon pipe, LED lamp, small tub, sectio set, thermometer, centrifuge. This study used the experimental method with Completely Randomized Design (RAL) because the experimental media was considered homogeneous. The Completely Randomized Design Model used is: Yij $=\mu+a i+\varepsilon i j$. The design was used 5 treatments and 4 replicates $((1 \%, 2 \%, 3 \%, 4 \%$ and $5 \%)$ and controls $\}$.

\subsection{Research procedure}

This research included extraction of cherry leaf, Phytochemical Extract Test, Solution Preparation Test, Parasite Preparation Test, Container Preparation Test, Soaking of Sangkuriang Catfish Seed in Cherry Leaf Extract and Hematocrit and Leukocrit Testing.

\subsection{Static Analysis}

Data analysis on the hematocrit and Leukocrit levels used the analysis of variance and the Smallest Differential Difference Test (BNT) to compare values between treatments. Description data was analyzed from a clinical symptom, microscope observation, and water quality. 


\section{Results and Discussion}

\subsection{Results}

\subsubsection{Extraction}

$4.5 \mathrm{~kg}$ of Fresh M. calabura cherry leaves could be extracted to be $1.25 \mathrm{~kg}$ of yield powder. Maceration results obtained $935 \mathrm{ml}$ then evaporated to $720 \mathrm{ml}$ that employed $96 \%$ ethanol with 4 liters $/ \mathrm{kg}$ of powder of cherry leaves, in ratio.

\subsubsection{Phytochemical test}

Phytochemical test was applied to identify cherry leaf compounds.

Table 1. Phytochemical test results of Cherry Leaf (Muntingia calabura)

\begin{tabular}{lll}
\hline Test & Results & Description \\
\hline Alkaloids & 1. Bening (Mayer Test) & $(-)$ \\
& 2. Bening (Test Bouchardat) & $(-)$ \\
Flavonoids & 3. Brownish brown sediment (Dragendorf Test) & $(+)$ \\
Tanin & The orange layer on amyl alcohol & $(+)$ \\
Saponin & The color is blackish green & $(+)$ \\
Steroid/ & There is a permanent foam on the top layer & $(+)$ \\
Terpenoid & Shaped green & $(+) /(-)$ \\
\hline
\end{tabular}

\subsubsection{Leukocrit}

Leukocrit was calculated to know the percentage of leukocyte content in sangkuriang catfish seeds infected by Trichodina sp pre- and post-immersion of cherry leaf extract. The results (Fig. 1) showed that cherry leaf extract (M. calabura) worked well against Trichodiniasis disease on sangkuriang catfish (C. gariepinus). It showed significant difference among treatment $(p<0.05)$. it revealed that the leukocrit treatment value of $1 \%$ was Pretreatment $20.15 \%$ and Post Treatment to $3.44 \%$, 2\% treatment was Pretreatment $24.39 \%$ and Post Treatment to $2.68 \%, 3 \%$ treatment was Pretreatment 24,68\% and Post Treatment to $4.48 \%, 4 \%$ treatment was Pretreatment $23.52 \%$ and Post Treatment to $7.56 \%$, treatment 5\% was Pretreatment $18.77 \%$ and Post Treatment to $5.77 \%$. Based on results, it showed that $4 \%$ of cherry leaf extract had the highest leukokrit percentage of Sangkuriang catfish seeds with $7.56 \%$, while the lowest percentage of leukokrit content was in $2 \%$ treatment with $2.68 \%$ level of leukokrit.

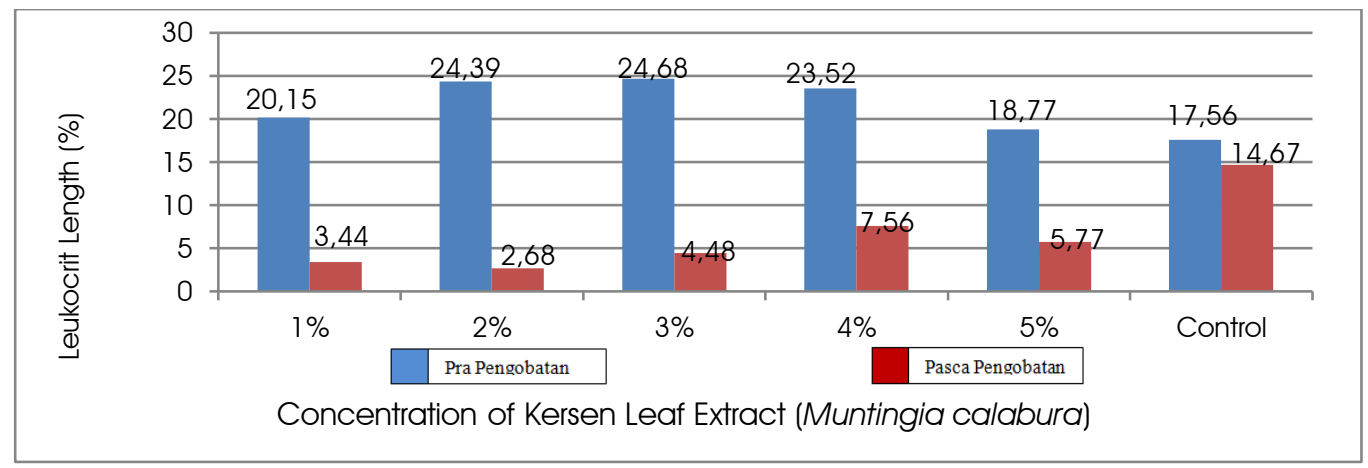

Figure 1. Percentage of Leukocrit Value

3.1.4. Hematocrit 
Hematocrit was measured to see the percentage of erythrocyte contents in catfish seed infested by Trichodina sp parasite post-immersion with cherry leaf extract. The percentage of hematocrit was observed in pre- and post-treatment.

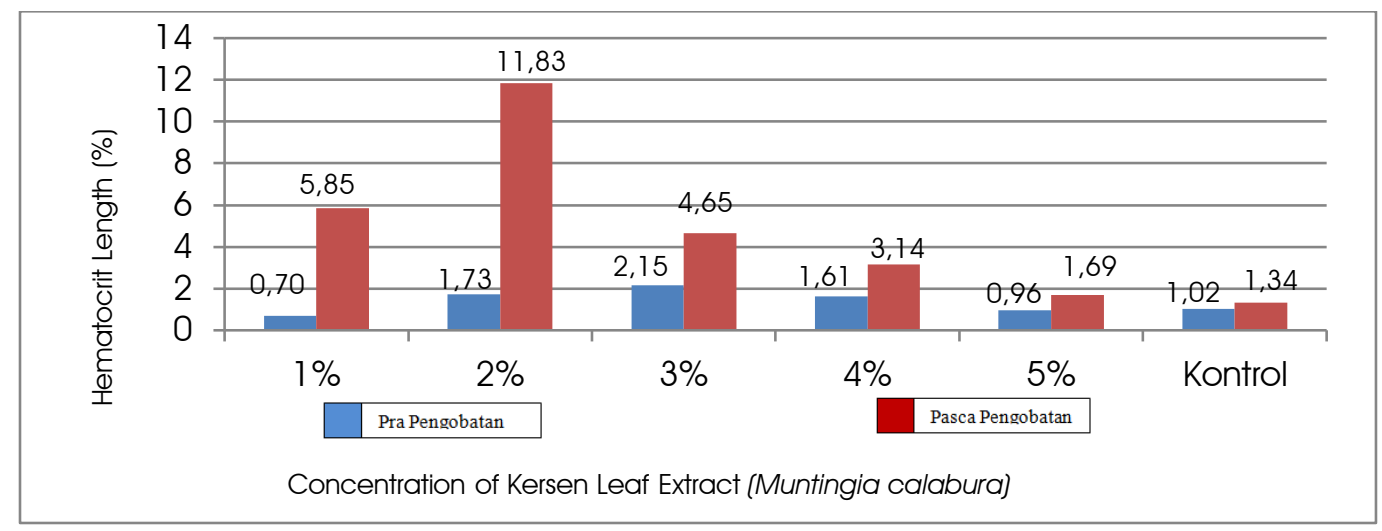

Figure 2. Percentage of Hematocrit Value

The results of variance showed cherry leaf extract ( $M$. calabura) as the treatment of Trichodiniasis disease significant different $(p<0.05)$ on sangkuriang catfish seeds ( $C$ gariepinus).

Based on fig. 2, showed that ematocrit values of treatment $1 \%$ were pre-treatment $0.70 \%$ and post-treatment to $5.85 \%, 2 \%$ treatment was $1.73 \%$ and post-treatment treatment became $11.83 \%$, treatment $3 \%$ was pre-treatment $2.15 \%$ post-treatment to $4.65 \%$, $4 \%$ treatment was $1.61 \%$ pretreatment to $3.14 \%$ post-treatment, $5 \%$ treatment was pre-treatment $0.96 \%$ and posttreatment to $1.69 \%$ and pre-treatment control $1,02 \%$ and post-treatment $1.34 \%$. Based on our results, it showed that $2 \%$ of cherry leaf extract the highest of hematocrit percentage of catfish seed with $11.83 \%$, then the lowest percentage of hematocrit content was at $5 \%$ by $1.69 \%$ level of hematocrit.

\subsubsection{Clinical Symptoms}

Clinical symptoms were applied to determine the specific conditions in the observed biota. The control group changed post-infected with wounds appeared in throughout body, abnormal swimming, many mucus and was given with a symbol $(+++)$. The $1 \%$ and $2 \%$ of $M$. calabura extract showed clinical changes on $18^{\text {th }}$ and $17^{\text {th }}$ day, respectively $(++)$ and the $7^{\text {th }}$ day $((+))$ and $(+)$ at $19^{\text {th }}$ day. The $3 \%$ concentration of $M$. calabura extract showed a better results. The clinical symptoms changed on $18^{\text {th }}$ day with the symbol $(++)$, on the $90^{\text {th }}$ day with the symbol $(+)$ and on the $20^{\text {th }}$ day with the symbol $((+))$. At the $4 \%$ concentration, it changed on the $19^{\text {th }}$ days with symbol $(++)$ and symbol $((+))$ on the $20^{\text {th }}$ day. The $5 \%$ concentration changed on the $19^{\text {th }}$ days with symbol $(++)$ and on a day to twenty with symbols $(++)$ and $((+))$.

The seeds of catfish was changed morphologically and physiologically post-infected by Trichodina sp. It was marked by the presence of white spots on the catfish body, excessive of mucus and rubbed their body on the wall. Infection of trichodina parasite could cause death in fish (host).

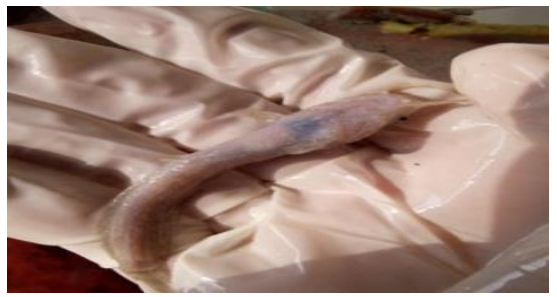

(a)

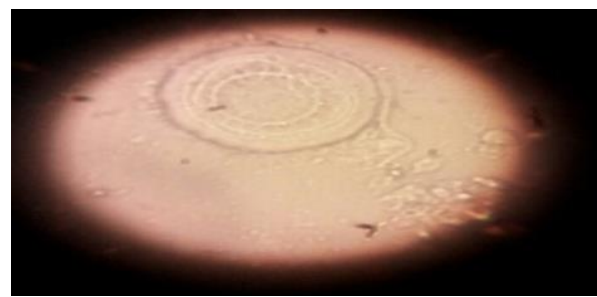

(b)

Figure 3. (a) Trichodina observation is macroscopic and (b) Microscopic 


\subsection{Discussion}

The immersion (maceration) was employed to obtain cherry leaf extract. According to Agoes (2007), maceration is a simple way of filtering. The solvent will penetrate into cell wall and cell cavity contained an active substance. The active compound will be dissolved because there is a difference of concentration between the active substance inside and outside cell. According to Krisdayanti (2011) and Kuntorini, et al. (2013), cherry leaf consists of dry material such as crude protein, crude oil, ether extract, neutral detergent fiber, acid detergent fiber, tannin compounds, flavonoids, and saponins. The extract was obtained $720 \mathrm{ml}$ using evaporation process. The ethanol was used to extract antimicrobial compounds from plants which are saturated aromatic and organic compounds. Based on Watunglawar (2013), ethanol had been employed to extract compound of cherry leaf extract (M. calabura L) to inhibit Vibrio harveyi. According to the description above, cucumber leaf extract was recommendable applied to treat Trichodina sp parasite on cultivation.

\subsubsection{Leukocrit}

Leukocrit value of catfish is $1-2 \%$ in normal condition. Leukocrit levels are less than $1 \%$ in chronic infection such as low nutritional quality, vitamin deficiency, and contaminants. Leukocrit levels are more than $2 \%$, probably due to early stage of infection and stress in catfish (Perera \& Pathiratne, 2008 in Husayin 2016). The results showed decreasing of leukokrit by all treatment in all time-manner. The $2 \%$ of cherry leaf extract showed the best effect to decrease catfish leukokrit compared among treatments ( $p>0.05)$. Decreasing of leukocrit percentage in this study is revealed that cherry leaf extract could inhibit Trichodina parasite infection. We speculate that is related to the content of active substances contained in cherry leaf extract (Table 1) that have been known as antioxidant, anti-bacterial and anti-microbial compound (Krisdayanti, 2011 and Kuntorini et al., 2013).

Flavonoids are phenol compounds that are disinfectant works by denaturing proteins that can cause microbial cell metabolic activity to stop because all microbial cell metabolism activity is catalyzed by an enzyme that is a protein. The cessation of this metabolic activity can lead to death in microbial cells. Flavonoids are also bacteriostatic which works by inhibition of bacterial cell wall synthesis (Selway, 1986). According to Sabir (2005), flavonoid compounds have the ability to inhibit the growth of bacteria with several different mechanisms, including flavonoids causing damage to the permeability of bacterial walls, microsomes, and lysosomes as a result of the interaction between flavonoids with bacterial DNA, different mechanisms proposed by In Carlo et al., (1995) and Estrela et al., (1995) in Sabir (2005), which states that hydroxyl groups present in the structure of flavonoid compounds cause changes in organic components and nutrient transport that will eventually lead to toxic effects on bacteria.

Cherry leaf extract (M. calabura) also contain tannin, which has ability to be antibacterial from proteins complexes and bind to bacterial cell walls to inhibit bacterial growth or enzyme activity (Smith et al., 2005). Other Cherry leaf (M. calabura) compound is saponin. Saponin is a strong active compound and could cause foam and has the ability as toxic to aquatic (fish). In other case, saponin compounds have the antibacterial ability with increase the permeability of bacterial cell membranes caused damage and lysis of cell (Robinson, 1995). Furthermore, Dwidjoseputro, (1994) suggests that saponins have molecules that can attract water or hydrophilic and molecules that can dissolve 
fat or lipophilic that can reduce the surface tension of cells that ultimately lead to the destruction of germs.

\subsubsection{Hematocrit}

Increasing of hematocrit level may indicate a contaminant, problem in osmolarity and stress. Decreasing of hematocrit levels indicate contamination condition such as lack of food, vitamin deficiency or infection, while in normal hematocrit values is ranged from $20-45 \%$ (Husin, 2016). The results showed increasing of hematocrit by all treatment in all time-manner. The highest increasing of catfish hematocrit level was showed by $2 \%$ of cherry leaf extract compared among treatments ( $p>0.05$ ). Increasing of hematocrit percentage in this study revealed that cherry leaf extract could inhibit Trichodina parasite infection.

Increasing of hematocrit is believed because of immersion of cherry leaf extract. Although the percentage of the hematocrit is not in normal range, it is possible because it is still in the recovery phase. According to Hussein, (2016) Hematocrit levels are influenced by the initial condition and handling of fish such as sampling fish blood. It could decrease of fish hematocrit level. In other case, Fish also has a anemia which make a percentage of hematocrit about $10 \%$. The low hematocrit level indicate contamination, lack of food, the low protein content of feed, vitamin deficiency or the occurrence of infection. The high of hematocrit may also show contamination, osmoregulation and stress problems (Hastuti, 2007). Fujaya (2004) in Hastuti (2007), there is a strong relationship between hematocrit and the amount of blood hemoglobin. The lower of red blood cells as same as the lower the hemoglobin blood contents.

Based our results, increasing of hematocrit values might be caused by active substances contained in cayenne leaf extract. Kuntorini et al., (2013) revealed that the content of cherry leaf compounds are flavonoids, saponins, triterpenoids, steroids, and tannins showed antioxidative activity. In previous studies suggested that those compounds are antioxidant, anti-bacterial and anti-microbial which at certain concentrations could disturb fish physiologically because of the endurance of fish to the extract. According to Sabir (2005), flavonoid compounds have ability to inhibit bacteria growth with different mechanisms, including flavonoids causing damage to the permeability of bacterial walls, microsomes, and lysosomes as a result of interactions between flavonoids and bacterial DNA.

\subsubsection{Clinical Symptoms}

Trichodina sp parasites interfere in freshwater activities. Trichodina sp parasite adhere in the skin, fins, and gills. The Fish infected by Trichodina sp become pale, decrease of appetite, slow motion, often rubbed on the wall, and irritation. Other clinical symptoms, white spots appear on the head and back and grow because of excessive mucus production (Khordi, 2010). Trichodiniasis in some cases cause several damage to the host, which lead to host mortality (Woo, 2006). The infection of Trichodina sp could be faster when the water condition is fit with their physiology. the level of pathogenicity is the ability to infect Trichodina $\mathrm{sp}$ is the prevalence and intensity (Irianto, 2005).

According to Woo (2006) and Basson (2010), Trichodina sp could be multiply by splitting rapidly and always moving actively to increase invasion intensity. The type and extent of Trichodina sp infection could be different because they affect in different area and stage of fish such as in feed, fish age, fish size, aquatic conditions and cultivation activities (Handayani et al., 2014). Based on Hadiroseyani et al., (2006), the high density of stocking will cause fish to touch each other which 
facilitate a transmission. The clinical symptoms of fish usually appear because of excessive mucus production and weak in behavior, skin lesions and fins slightly damaged. Parasites in large quantities in the gills could disturb fish breathing and damage gill epithelium. High mortality generally is occured in small fish (Ansari, 2008). According to Pramono and Hamdan (2008), Trichodina sp parasites in high intensity could damage to the gill structure and leads to death. Actually, this parasite is not the main pathogen because they infect fish after other factors appear such as injury, pain, and stress. This parasite makes the fish body as a sticky place (substrate) and takes organic particles from bacteria attached to the skin of fish caused wounds. Attachment to the gills cause injuries and frequent red blood cells in the Trichodina sp food vacuole. In this condition, Trichodina $\mathrm{sp}$ is a true ectoparasite (Rahayu, 2009).

\subsubsection{Water quality}

Water is a habitat for aquatic animals especially fish, therefore water parameters are kept within the optimum range that could support the life and growth of fish. Sangkuriang catfish is a type of fresh fish whose is influenced by environmental factors. In this research, water quality measurements were observed such as temperature, $\mathrm{pH}$, and DO. These parameters were observed every morning/day.

Table 2 Parameter Range Water quality at the time of study

\begin{tabular}{lccc}
\hline \multirow{2}{*}{ Treatment } & \multicolumn{3}{c}{ Parameter } \\
\cline { 2 - 4 } & Temperature $^{\circ} \mathrm{C}$ & $\mathrm{pH}$ & $\mathrm{DO}(\mathrm{ppm})$ \\
\hline Control & $24-27,2$ & $6-8$ & $4,1-6,3$ \\
Treatment & 24,27 & $6-8$ & $4,1-6,9$ \\
\hline
\end{tabular}

Based on table 2, it was known that the temperature in range from $24-27.2^{\circ} \mathrm{C}$, DO (Dissolved Oxygen) range from $4.1-6.9 \mathrm{ppm}$ and the $\mathrm{pH}$ of water in range from 6-8. The quality of water during the study was still in accordance and feasible for the life of catfish. According to Suryaningsih, (2014) catfish could live optimally on the DO range of $4 \mathrm{mg} /$ liter, $\mathrm{pH}$ range 6-8 and temperatures ranging from $26-29^{\circ} \mathrm{C}$.

\section{Conclusions}

Cherry Leaf Extract (M. calabura) has an effect to treat Trichodiniasis disease revealed by decreasing value of Leukocrit presentation on blood of Sangkuriang catfish, increasing of the percentage of Hematocrit and body condition of Sangkuriang catfish begin to normal (healthy). The $2 \%$ concentration is the optimal concentration to treat Trichodina sp parasite, with the value of Leukocrit percentage of $24.39 \%$ post- infected and to $2.68 \%$ post-treatment. The percentage value of Hematocrit was $1.73 \%$ post- infected and to $11.83 \%$ post-treatment.

\section{References}

Agoes G. 2007. Natural Materials Technology. ITB. Bandung

Husein A. 2016. Giving of Alginate Sargassum Sp. From Nusakambangan White Sand Beach To Improve Non-Specific Catfish Defense System (Clarias Sp.) [Thesis]. Fishery Cultivation Study Program Faculty of Agriculture, University of Gadjah Mada Yogyakarta 
Anshari H. 2008. Level of Parasite Infection on Mas Koki Fish (Cyprinus carpio) at Multiple Locations of Ornamental Fish Farming in Makassar and Gowa (Parasitic Infections of Koi Carp Cultured in Makassar and Gowa). J Science \& Tech8 (2): 139-147.

Basson L. 2010. First records of Trichodinid ectoparasites (Ciliophora: Peritrichia) from included freshwater fishes in Tasmania, Australia, with comments of Pathogenicity. Acta Parasitologica 49 (3) pp. 253-265

Chanif M. 2012. Know the Dangers of Formalin, Dark and Dangerous Dyes in Food.

Dwijoseputro D. 1987. Fundamentals of Microbiology. Djambatan. Jakarta.

Gusrina. 2008. Fish Cultivation Volume 3. Jakarta: Directorate of Vocational High School Development.

Hadiroseyani $Y$, Hariyadi $P$, and Nuryati S. 2006. Inventory of parasitic catfish dumbo Clarias sp. in the Bogor area. Indonesian Aquaculture Journal 5 (2) pp. 167-177

Handayani R, Adiputra YT, Wardiyanto. 2014. Identification and diversity of parasites in carp fish (Carassius auratus) and carp (Cyprinus carpio) originating from Lampung and beyond Lampung. Journal of Fisheries Science and Water Resources.

Hastuti SD. 2007. Evaluation of non-specific defenses of tilapia (Oreochromis sp) injected with LPS (Lipopolysaccharides) of Aeromonas hydrophilia. Department of Fisheries, Faculty of Animal Husbandry - Fisheries University of Muhammadiyah Malang.

Husayn A. 2016. Giving of Alginate Sargassum Sp. From Nusakambangan White Sand Beach To Improve Non-Specific Catfish Defense System (Clarias Sp.) [Thesis]. Fishery Cultivation Study Program Faculty of Agriculture, University of Gadjah Mada Yogyakarta

Indriani AD, Prayitno SB, Sarjito. 2014. The use of red ginger extract (Zingiber officinale var Rubrum) as an alternative treatment of tilapia (Oreochromis niloticus) infected by Aeromonas hydrophila bacteria. Journal of Aquaculture Management and Technology, 3 (3): 58-65.

Irawan A. 2004. Tackling Pest and Fish Disease. CV. Multifarious. Solo.

Irianto A. 2005. Teleostei Fish Pathology. Gadjah Mada University Press, Yogyakarta.

Kordi MGH. 2010. Fish Cultivation In The Tarp Pond. Andi Publisher. Yogyakarta

Krisdayanti N, Ramin DN, Naser MS, Abolfazl G. 2011. Degradation of Rumen and Digestion of Dry Materials and Organic Material Using Cherry Tree Leaves In Vitro Gas Production and In Situ Technique. Department of Animal Science. Shabestar branch of Islamic University of Azad. Iran.

Kuntorini MV, Fitriani S, Astuti DM. 2013. Anatomical Structure and test of antioxidant activity and methanol extract of Cherry Leaf (Muntingia calabura). University of Lampung Mangkurat. Proceeding semrata FMIPA University of Lampung.

Mahasri G. 2009. Description of Gill Pathology and Shrimp Skin Windu (Penaeus Monodon. Fab) Who Ciliata Pathogen From the Family Orticellidae (Zoonthanium sp.) Journal Ilmiah Fishery Surabaya: Faculty of Fisheries and Marine University of Airlangga. 3: 1

Pramono TB, Hamdan S. 2008. Parasite Infection on the Nilem Fish Body Surface (Osteochitus hasellti) Traded in PPI Purbalingga. Islamiah Fisheries Period: 79-82.

Priharyanti D. 2007. Muntingia calabura. http://florabase.calm.wa.gov.au/ browse / flora? $f=220$ \& level $=\mathrm{f} \&$ id $=220$ (July 15, 2013).

Rahayu DI. 2008. Production of natural antibiotics results of isolation Aloe barbadensis Miller: penangulanggan mastitis on dairy cattle. Grant research report.

Robinson T. 1995. High-Level Organic Plant Content, ITB: Bandung 
Sabir A. 2005. Antibacterial Activity of Flavonoid Propolis Trigona sp against Streptococcus mutans (in vitro). Dental Journal (Dent J) 38: 135-141

SNI 01-6729-2002. About Organic Food

Selway, J.W.T. 1986. Antiviral Activity of Flavones and Flavons. Plant Flavonoids in Biology and Medicine: Biochemical, Pharmaceutical, and Structure-Activity Relationships. Alan R. Liss, Inc. p: 521-536.

Sentat, T. 2016. Test of Analgesic Effect of Ethanol Cherry Leaf Extract (Muntingia calabura L.) on White Mice (Mus musculus) with Induced Acetic Acid Pain. 2 (2), 147-153

Smith, Alli, and Adanlawo, I.G. 2014. In Vitro and in vivo antioxidant activity of saponin extracted from the root of garcinia kola (Bitter Kola) o Alloxan-Induced Diabetic Rats. In word journal Pharmacy and Pharmaceutical Science. 3 (7): 8-26.

Sulistyaningrum, M. 2014. Test of antibacterial activity of ethanol extract of Cherry Leaf (Muntingia calabura L.) against Klebsiella pneumoniae bacteria. Faculty of mathematics and science. Sebelas Maret University. Surakarta

Suryaningsih, S. 2014. Biology of Catfish. Ministry of National Education. Faculty of Biology. University General Soedirman. Purwokerto.

Yuasa, et al. 2003. Diagnosis Guide for Fish-II Disease. Central Research of marine aquaculture fishery gondol and Japan international coorporation (JICA). Bali.

Watunglawar, M. 2013. Cherry Leaf Extract Power Test (Muntingia Calabura L) Against Growth of Vibrio Harveyi Bacteria Attacking Shrimp. [Thesis] Department of Fisheries Faculty of Agriculture and Animal Husbandry University of Muhammadiyah Malang.Woo JL. 2006. FishDisease and Disorder Parasite. University of Guelph \& CAB International, Canada.

Zakaria Z. A. 2007. Free radical scavenging activity of some plants available in Malaysia. IJPT.6: 8791.

Zheila, P.R.N. 2013. Prevalence and Intensity of Trichodina sp. On the Seed of Nile Fish (Oreochromis niloticus) in Tambakrejo Village, Kecamtan Pacitan, Pacitan Regency. Biology department. Faculty of Math and Science. Sepuluh Nopember Institute of Technology. Surabaya. 